\title{
Yield Trials of Leucaena in the U. S. Virgin Islands ${ }^{1}$
}

\author{
A. J. Oakes ${ }^{2}$ and O. Skov ${ }^{3}$
}

INTRODUCTION

The widespread distribution and multifarious utilization of Leucaena leucocephala (Lam.) de Wit are well known. The economic importance of this arborescent, pantropic, versatile legume was first recognized for its value as a shade and green manure crop in coffee, tea, and rubber plantations. It was widely used in reforestation and for erosion control long before its value as a forage plant became known.

Forage high in protein and total digestible nutrients (TDN) is badly needed in the Tropics, especially in widespread areas of the dry Tropics, to supplement the protein deficiency commonly prevalent in these areas. During the recurring dry seasons, characteristic of the dry Tropics, pasture and range grasses are low in quantity and particularly low in protein. An adequate and constant supply and cheap source of protein are invaluable to success of livestock enterprises in tropical agriculture.

There is a constant need for a perennial, deep-rooted, drought-tolerant legume, capable of sustained heavy production of forage high in palatability, protein, TDN content, and livestock acceptance. The protein and roughage requirements of livestock enterprises in many areas of the dry Tropics and subtropics may be met, at least partly, through use of this versatile legume.

\section{PLANT CHARACTERISTICS}

This versatile legume possesses certain desirable characteristics necessary to fulfill, at least partly, the protein requirements of livestock enterprises in the dry Tropics. These salient characteristics include: 1, Copious seed production; 2, deep root system; 3 , tolerance of drought and deficiencies of iron and phosphorus; 4, ease of establishment and rapid growth rate; 5 , persistence of stand capable of sustained high production; 6 , high nutritive value, protein content, palatability, and animal acceptance; and 7 , tolerance of hazards and pests.

The plant thrives best in full sun on deep fertile soils supplied with

${ }^{1}$ Contribution from Virgin Islands Agricultural Research and Extension Program, Agricultural Research Service, U.S. Department of Agriculture, Kingshill, St. Croix, U.S. Virgin Islands.

${ }^{2}$ Research Agronomist, Crops Research Division, Agricultural Research Service, U.S. Department of Agriculture, Beltsville, Md.

${ }^{3}$ Research Technician, Agricultural Research Service, U.S. Department of Agriculture, Kingshill, St. Croix, U.S. Virgin Islands. 
adequate moisture. The deep, fast-growing taproot and xerophytic leaf movement contribute to the plant's drought tolerance. Copious seed production, sustained longevity of seed viability, and, especially, the vigorous and rapid growth of ratoon crops, ensure stands and sustained high forage production. The ability of the plant to thrive in difficult sites on shallow infertile soils deficient in iron and phosphorus, in rainfall belts of 20 to 80 inches per year from near sea level to 3,000 feet, increases its usefulness and extends production range.

The plant recovers rapidly following rains, a valuable attribute, especially for the dry Tropies. The growth rate and production of the plant depend largely upon natural soil fertility and rainfall; however, increased yields result from the use of fertilizers and irrigation. In addition to its sustained forage production, high yield, nutritive value, protein, and TDN content, the plant improves the soil in two ways. The nitrogen and phosphorus content of soils is increased by growing the crop. Nitrogen is constantly added through nodulation and by the constant dropping of leaves. The deep, fast-growing taproot pierces hard soil strata and brings essential plant foods to the surface, thus enriching the soil.

In view of its widespread adaptation to, and natural occurrence in wide ranges of elevation, soil types, and moisture and fertility levels, certain basic agronomic factors should be considered prior to establishing the plant as a field crop. Practical questions deserving consideration prior to establishing the crop include: 1 , Seedbed preparation; 2, weed control; 3 , method of planting; 4, seeding rate; 5 , row spacing; 6 , cultural practices; 7 , irrigation and/or fertilization; 8, management; and 9, utilization.

The nutritive value, animal acceptance, and benefits derived through the use of this legume as a source of roughage and protein are equivalent to those obtained through the use of alfalfa, the legume with which all other legumes are usually compared. The nutritive value and protein content of grasses are increased when they are grown in association with Leucaena.

The palatability of grasses is improved when they are fed with Leucaena. The nutritive value and protein content of green and dry forage are equal or superior to those of alfalfa. Forage analyses indicate that protein content ranges from 5 to 8 percent for green forage and 15 to 30 percent for dry forage. The carotene and vitamin A contents of the forage are also superior to those of alfalfa. Chemical analyses of dehydrated leafmeal and silage indicate that they are excellent sources of carotene and protein for livestock. The TDN content and coefficient of digestibility are equivalent to those of alfalfa. The palatability and nutritive value of silage and soilage are improved through the use of $L$. leucocephala.

Its livestock acceptance is excellent. The foliage, including flowers, leaves, seedpods, seeds, twigs, and young stems, whether mature or im- 
mature, green or dry, is palatable to and relished by all types of livestock. The forage furnished by this highly proteinaceous legume is eaten by browsing livestock, and is also consumed as silage, soilage, and in dry and dehydrated form. Drying or dehydration and storage do not alter the carotene and protein contents or the nutritive value of the forage.

Its widespread adaptation and drought-tolerance and its ability to grow in areas where grasses fail, producing sustained heavy yields of forage high in quality and nutritional value, make this perennial, versatile legume valuable as a browse plant. High palatability, and also compatibility with fast-growing highly productive pasture grasses, facilitate the careful management that it requires when it is used as a pasture legume.

Both under- and overgrazing must be guarded against when the plant is browsed. The plant aids in preventing erosion, furnishes shade, and enriches the soil when employed as a pasture legume. The harvested forage enjoys wide usage as silage and soilage as the chief source of roughage for dairy cattle; it is usually fed in association with grasses.

The plant serves as a cheap source of protein, both in green and dry form, for all types of livestock, including chickens, cattle, goats, horses, sheep, and swine. Its high nutritive value, palatability, ca rotene, protein and vitamin $\mathrm{A}$ content make the forage desirable to and valuable for all types of livestock. This legume has one serious drawback as a livestock feed, however,-its toxicity to livestock, particularly to nonruminants. There is abundant evidence that $L$. leucocephala is an excellent and cheap source of protein for the livestock industry of the dry Tropics, despite its toxicity.

Agronomic research began with the plant in Hawaii prior to World War II, and since that time, many of the problems in its production, management, and utilization as a forage crop have been worked out. Information contained in the literature about the establishment, cultivation, management, and utilization of the plant as a forage crop is voluminous. Excellent reviews of the subject have been made. Details on the production, management, and utilization of the crop for forage have been reported previously; e.g., Dijkman (2) ${ }^{4}$, Hutton and Gray (5), Kinch and Ripperton (6), Oakes and Skov ( $(7)$, and Takahashi and Ripperton (9).

The paucity of data on its yield capability and the known genetic variation within the species lend emphasis to the need for additional information on the production capacity of different strains of this versatile legume.

\section{MATERIALS AND METHODS}

These trials were conducted in St. Croix, U. S. Virgin Islands, where the mean temperature is $79^{\circ} \mathrm{F}$., with monthly averages ranging from $76^{\circ}$ to

${ }^{4}$ Italic numbers in parentheses refer to Literature Cited, p. 181. 
$82^{\circ} \mathrm{F}$. The highly variable rainfall ranged from one-quarter to nearly 9 inches per month during the test period. The mean monthly rainfall during the test period was 2.61 inches. The open-pan evaporation rate is over 72 inches per annum. Fredensborg clay was used for the investigation; this heavy clay soil averages 1 to 3 feet in depth and is underlaid by loose marl which reduces its water-holding capacity. The soil $\mathrm{pH}$ at the surface ranges between 6.8 and 7.5.

Eight strains of $L$. leucocephala, from widely separated areas in the Tropics, in addition to L. esculenta (M. \& S.) Benth. and L. lanceolata S. Wats., were established in field plantings in January 1964. The crop was established by seeding. Weed control was accomplished by use of the hoe; this was necessary before the planted crop formed a ground cover and at sporadic intervals following the ratoon crops. A randomized-block design was used with eight replications, each block consisting of three rows 2.5 feet wide with the plants 1.5 feet apart within the row. Dry-matter and nitrogen determinations were made from samples taken from the middle row.

Drying was in a forced-air drier at $110^{\circ}$ to $125^{\circ} \mathrm{F}$., and nitrogen was determined by the Kjeldahl method. Harvesting was by machete; the plants were cut about 2 inches above ground. The plant crop was harvested in August, 7 months after establishment; the two succeeding ratoon crops were harvested at intervals of 4 to 5 months.

\section{RESULTS AND DISCUSSION}

A summary of dry-matter and protein yields is given in table 1 . The dry-matter yields are comparable to those reported from other trials by Anslow (1), Hutton and Bonner (4), and Oakes and Skov (7). Dry-forage yields range from 6 to 9 tons per acre annually in Hawaii where moisture is adequate. Based on the premise of 3.5 inches of rainfall per month required for optimum growth, optimum yields were not achieved, according to Halais (3), and Takahashi and Ripperton (9). Based on the known yield potential for the species, it is considered that the amount and, particularly, the poor distribution of rainfall limited production in these trials. Rainfall had a marked influence on production, and higher yields were obtained during periods of higher rainfall. The yield superiority of strains from Australia, El Salvador, and Guatemala over that of the local strain, P.I. 281605 (USDA Plant Introduction No.) is of interest. The Salvador type is known to be larger in size than the West Indies strain. These yield data confirm the reported variation between strains regarding growth rate and yield.

The protein yields, ranging from about $1 / 2$ to over 1 ton per acre annually, are comparable to those reported from other trials e.g.: Anslow (1), Hutton and Bonner (4), Oakes and Skov (7), Takahashi and Ripperton (8), and Takahashi et al. (9). The highest yield obtained is equivalent to that 
reported by Whyte (10) where the crop was irrigated. The protein content was determined from dry forage. The protein percentage indicates that the high yields of protein are to be ascribed to increased yield of dry matter rather than to protein content. Any of these strains producing 5 to 10 tons of dry forage annually, containing 14 to 16 percent of protein, would serve as an excellent source of high-protein forage in the dry Tropics.

TABLE 1.-Yield, tons of dry matter and pounds of protein, per acre per year of 10 strains of Leucaena ${ }^{1}$

\begin{tabular}{|c|c|c|c|c|c|c|}
\hline \multirow{3}{*}{ Strain No. } & \multirow{3}{*}{ Source } & \multirow{3}{*}{ P.I. No. ${ }^{2}$} & \multicolumn{4}{|c|}{ Yield } \\
\hline & & & \multicolumn{2}{|c|}{ Dry matter } & \multicolumn{2}{|c|}{ Protein } \\
\hline & & & Tons & $\begin{array}{c}\text { Statistical } \\
\text { significance }\end{array}$ & Percent & Pounds \\
\hline 4 & Guatemala & 284758 & 8.28 & a & 15.3 & 2550 \\
\hline 5 & El Salvador & - & 7.36 & $a b$ & 15.9 & 2312 \\
\hline 7 & Australia & 282469 & 6.43 & bc & 14.9 & 1945 \\
\hline 3 & Peru & 281772 & 6.08 & bed & 15.4 & 1892 \\
\hline 2 & Philippines & 188810 & 5.14 & cde & 15.2 & 1570 \\
\hline 8 & Hawaii & 284759 & 5.01 & ede & 16.0 & 1585 \\
\hline 9 & Virgin Islands & 281605 & 4.47 & def & 16.2 & 1492 \\
\hline 1 & Philippines & 290753 & 4.23 & ef & 15.4 & 1319 \\
\hline $11^{4}$ & Mexico & 294093 & 3.40 & ef & 14.4 & 943 \\
\hline $10^{5}$ & Do. & 286248 & 2.99 & $\mathrm{f}$ & 14.0 & 832 \\
\hline
\end{tabular}

${ }^{1}$ L. leucocephala (Lam.) de Wit (unless otherwise shown).

${ }^{2}$ USDA Plant Introduction No.

${ }^{3}$ Means average significantly different at 5-percent level by Duncan's Multiple Range, if not followed by any letters in common.

${ }^{4}$ L. lanceolata S. Wats.

${ }^{5}$ L. esculenta (M. \& S.) Benth.

\section{SUMMARY}

The yield of 10 strains of Leucaena from widely separated regions in the Tropics was determined in replicated field trials. Yields varied from 3 to 8 tons of dry forage per acre per year between strains; these differences in yield are significant. The superiority of strains of $L$. leucocephala from Guatemala, El Salvador, Australia, and Peru is shown. Annual yields of protein varied from 832 to 2,550 pounds per acre. The protein content of dry forage ranged from 14 percent for L. esculenta from Mexico to 16.2 for a strain of $L$. leucocephala from the U.S. Virgin Islands. Any of these strains, producing 5 to 10 tons of dry forage and a ton of protein per acre annually, would serve as an excellent protein source for livestock enterprises in the dry Tropics. 


\section{RESUMEN}

Se determinó en múltiples pruebas de campo, el rendimiento de 10 tipos (strains) de Leucaena procedentes de apartadas regiones del Trópico. Los rendimientos de los distintos tipos fluctuaron entre 3 y 8 toneladas de forraje seco por acre por año. Tales diferencias en rendimiento son significativas. Se muestra la superioridad de los tipos de L. leucocephala originados en Guatemala, El Salvador, Australia y Perú. Los rendimientos de proteína fluctuaron entre 832 y 2,550 libras por acre. El contenido de proteína del forraje seco varió de 14 por ciento en $L$. esculenta procedente de México a 16.2 por ciento en un tipo de $L$. leucocephala oriunda de las Islas Vírgenes de los Estados Unidos. Cualquiera de estos tipos con una producción de 5 a 10 toneladas de forraje seco y 1 tonelada de proteína por acre por año, podría servir como excelente fuente de proteína para el ganado en los Trópicos secos.

\section{LITERATURE CITED}

1. Anslow, R. C., Investigation into the potential productivity of "Acacia" (Leucaena glauca) in Mauritius, Rev. Agr. et Sucr. de L'Ile Maurice 36: 39-49, 1957.

2. Dijkman, M. J., Leucaena-A promising soil-erosion control plant, Econ. Bot. 4: $337-49,1950$.

3. Halais, P., L'exploitation intensive d'une legumineuse fourragere tropicale: Leucaena glauca, La Rev. Agr. 29: 68-74, 1950.

4. Hutton, E. M., and Bonner, I. A., Dry matter and protein yields in four strains of Leucaena glauca Benth., Austr. Inst. Agr. Sci. J. 26: 276-7, 1960.

5. Hutton, E. M., and Gray, S. G., Problems in adapting Leucaena glauca as a forage for Australian Tropics, Empire J. Expt. Agr. 27: 187-96, 1959.

6. Kinch, D. M., and Ripperton, J. C., Koa Haole, Production and Processing, Hawaii Agr. Expt. Sta. Bull. 129, 58 pp., illus., 1962.

7. Oakes, A. J., and Skov, O., Some woody legumes as forage crops for the dry Tropies, Trop. Agr. 39: 281-7, 1962.

8. Takahashi, M., and Ripperton, J. C., Koa Haole (Leucaena glauca): Its Establishment, Culture and Utilization as a Forage Crop, Hawaii Agr. Expt. Sta. Bull. 100, 56 pp., illus., 1949.

9. Takahashi, M., Ripperton, J. C., and Shigeura, Gordon, Koa haole, Hawaii Agr. Expt. Sta. Rept. 1941-42, pp. 76-7, 1943.

10. Whyte, R. O., The Provision of Animal Fodder in Tropical and Subtropical Countries, Imperial Bureau Pasture and Forage Crops Bull. 31, 84 pp., illus., 1944 . 